\title{
Effect of Rice Straw Biochar on Soil Quality and the Early Growth and Biomass Yield of Two Rice Varieties
}

\author{
Alie Kamara ${ }^{*}$, Hawanatu Sorie Kamara², Mohamed Saimah Kamara ${ }^{3}$ \\ ${ }^{1}$ Department of Soil Science, School of Agriculture, Njala University, Njala, Sierra Leone \\ ${ }^{2}$ Njala Agricultural Research Centre, Njala University Campus, Njala, Sierra Leone \\ ${ }^{3}$ Department of Agriculture, Ahmadiyya Secondary School, Freetown, Sierra Leone \\ Email: ${ }^{*}$ aliekamara@njala.edu.sl
}

Received 30 June 2015; accepted 15 August 2015; published 18 August 2015

Copyright (C) 2015 by authors and Scientific Research Publishing Inc.

This work is licensed under the Creative Commons Attribution International License (CC BY). http://creativecommons.org/licenses/by/4.0/

(c) (i) Open Access

\section{Abstract}

Sustainable rice production in Sierra Leone faces serious constraints due to soil acidity, low cation exchange capacity, low nutrient contents accelerated mineralization of soil organic matter and soil loss by erosion (particularly on the uplands). One possible approach to addressing the soil constraints to rice production both on uplands and lowlands of Sierra Leone is the recycling of rice residues through biochar production and application to soils. A pot experiment was conducted to investigate the effects of application of biochar from rice residues on (i) soil physicochemical properties and (ii) the early growth characteristics of two rice varieties, NERICA L19 and ROK3. The experiment was arranged in a completely randomized design (CRD) with two biochar levels (0 and $15 \mathrm{~g} / \mathrm{kg}$ soil) and two rice varieties in three replications. For the biochar treated soils (+biochar), $75 \mathrm{~g}$ rice straw biochar was applied to $5 \mathrm{~kg}$ air-dry soil (15 $\mathrm{kg}$ biochar/ $\mathrm{kg} \mathrm{soil),} \mathrm{mixed}$ thoroughly and placed into perforated black polythene bags. Seeds of two rice varieties, NERICA L19 and ROK3 were planted on the treated and untreated soils for eight weeks. Application of biochar improved available phosphorus, exchangeable cations and cation exchange capacity in biochar treated soils compared to the control soil without biochar. Plant height, tiller number, and dry biomass weight of both rice varieties grown in soils amended with rice straw biochar were significantly higher than those on untreated soils. The most remarkable increase in plant growth characteristics as a result of biochar addition to soil was reflected in the biomass yield and tiller numbers. Dry shoot biomass for ROK3 rice variety varied significantly from a mean of $\mathbf{3 . 5} \mathbf{g}$ (control) to $26.2 \mathrm{~g}$ (+biochar) while tiller numbers significantly varied from 10 (control) to 29.6 (+biochar). Similarly, for NERICA L19 rice variety, dry shoot biomass increased significantly from $4.5 \mathrm{~g}$ (control) to $22.7 \mathrm{~g}$ (+biochar) while tiller numbers increased significantly from a mean of 12.3 (control) to 30 (+biochar). Thus converting rice residues to biochar and applying to soil holds

\footnotetext{
*Corresponding author.
}

How to cite this paper: Kamara, A., Kamara, H.S. and Kamara, M.S. (2015) Effect of Rice Straw Biochar on Soil Quality and the Early Growth and Biomass Yield of Two Rice Varieties. Agricultural Sciences, 6, 798-806.

http://dx.doi.org/10.4236/as.2015.68077 
promise for improving rice production in Sierra Leone.

\title{
Keywords
}

\author{
Rice Straw, Biochar, NERICA L19, ROK3, Rice Growth
}

\section{Introduction}

Rice production in Sierra Leone faces large constraints due to soil acidity, low cation exchange capacity, low nutrient contents and accelerated mineralization of soil organic matter and soil loss by erosion. Consequently, low rice yield is prevalent in many rice production systems of Sierra Leone. Addressing this challenge requires judicious efforts such as recycling of crop residues, liming and fertilizer application, and erosion control.

A large quantity of rice residues are produced annually in rice cropping systems of Sierra Leone. Most of these residues are regarded as wastes and either burnt or piled and abandoned at some locations in the rice fields. Burning of rice residues result in substantial loss of nutrients such as, nitrogen and sulphur, and may lead to air pollution [1]-[3]. One possible approach to addressing the soil fertility constraints to rice production both on uplands and lowlands of Sierra Leone is the recycling of rice residues [4]. Rice residues can be recycled by composting or by direct incorporation into the soil. Applying residues in the form of compost or by direct incorporation into the soil could result in rapid decomposition and the release of nutrients, as well as, emissions of greenhouse gases such as carbon dioxide. This approach requires annual additions of the organic material to the soil to maintain fertility. An alternative approach which can be more sustainable is conversion of crop residues into biochar and application onto soil. Biochar is the carbon-rich charred remains from heating biomass in little or no oxygen conditions [5] [6]. Biochar has been estimated to have a half-life in the range of hundreds to thousands of years depending on biochar type and production conditions [7]. This is because the form of carbon in biochar is stable with a predominant aromatic structure that is resistant to decomposition [8]-[10]. Consequently, biochar has the potential to remain in the soil for hundreds to thousands of years [11] [12]. Thus the use of biochar as a soil amendment will impart properties to the soil with longer lasting effects than uncharred organic materials such as compost, manure or crop residues.

Biochar application to soils has been shown to improve soil physical and chemical properties [13]-[17]. Biochar is reported to have positive effects on soil acidity and improve nutrient and water retention capacity [18] [19], and hence, crop yields [13] [14] [20]-[23].

The use of biochar for improving soil and crop productivity has captured the interest of researchers, policy makers and farmers globally and has been at the center of active research recently. In Sierra Leone, very little attention has been given to this new area of research. This study was therefore undertaken to investigate the effects of application of biochar derived from rice straw on (i) soil physicochemical properties and (ii) the early growth of two rice varieties.

\section{Materials and Methods}

\subsection{Description of the Study Area}

The experiment was conducted in Njala Campus, Njala University in the Moyamba District in Southern Sierra Leone. Njala is located on Latitude $8^{\circ} \mathrm{N}$ and Longitude $12^{\circ} \mathrm{W}$, and is about $47 \mathrm{~km}$ from the second largest city, Bo City, and about $255 \mathrm{~km}$ from Freetown, the capital city of Sierra Leone.

The climate of the study area is tropical and is characterized by a rainy season between May and October and a dry season from November to April. The mean annual temperature varies from a minimum of $28^{\circ} \mathrm{C}$ and a maximum of $33^{\circ} \mathrm{C}$. The average annual rainfall is about $2500 \mathrm{~mm}$.

\subsection{Soil Sample and Analysis}

The soil sample for the trial was collected from the Mokonde fine sandy loam (Mokonde soil series) classified as a Plinthic Paleudult [24]. The soil has a 35 - $40 \mathrm{~cm}$ gravel-free top soil over gravel subsoil. A composite soil sample was collected from a depth of $20 \mathrm{~cm}$ and taken to the laboratory. The soil sample was air-dried and a 0.5 
kg sub-sample taken for physicochemical analysis. The rest of the sample was used for setting up the pot experiment.

Soil analysis was carried out for the composite sample before the trial and for separate biochar treated soil after two weeks of incubation. Soil $\mathrm{pH}$ was measured using a 1:1 soil to water ratio with a $\mathrm{pH}$ meter. Organic carbon was determined by the Walkley-Black procedure [25]. Cation exchange capacity was measured using the sodium saturation method. Exchangeable cations ( $\mathrm{Na}, \mathrm{K}$, $\mathrm{Ca}$, and $\mathrm{Mg}$ ) were extracted with $1 \mathrm{M}$ ammonium acetate buffered at pH7. Exchangeable $\mathrm{Na}$ and $\mathrm{K}$ were determined in a flame photometer while $\mathrm{Mg}$ and $\mathrm{Ca}$ were determined by EDTA titration. Particle size analysis was performed using the hydrometer method [26].

\subsection{Production of Rice Straw Biochar and Analysis}

Rice straw was collected from a rice farm in Mosongo village just outside Njala University Campus and allowed to dry thoroughly under the sun. Biochar was produced from the rice straw using a top-lit-updraft stove (the Elsa stove designed for the EU-funded Biochar ("BeBi”) Project in West Africa—EuropeAid/127860/D/ACT, FED/ 2009/221814). Rice straw was placed in the large Elsa burner and ignited. The hot biochar produced after pyrolysis was quenched with distilled water, collected and sun-dried, weighed and stored.

Rice straw biochar was analysed for bulk density, $\mathrm{pH}$, cation exchange capacity (CEC), and exchangeable cations ( $\mathrm{Na}, \mathrm{K}, \mathrm{Mg}$, and $\mathrm{Ca}$ ). The bulk density was determined as described by Ahmedna et al. [27]. Ground biochar was placed in a pre-weighed $10 \mathrm{ml}$ measuring cylinder and tapped gently with incremental additions until the $10 \mathrm{ml}$ mark was reached. The weight of cylinder containing the biochar was recorded and bulk density was calculated by dividing the weight of the dry biochar sample by 10 (the volume of the packed biochar). The $\mathrm{pH}$ was measured as described by [28]. Briefly, a $1 \%$ suspension of the biochar in de-ionized water was heated to about $90^{\circ} \mathrm{C}$ and stirred for 20 minutes. The suspension was then cooled to room temperature and the $\mathrm{pH}$ was measured with a pH-meter. CECwas determined by Na saturation as described by [29] except that Na was determined by flame photometry instead of atomic absorption spectroscopy. Available phosphorus and cations ( $\mathrm{Na}, \mathrm{K}, \mathrm{Mg}$, and Ca) were determined by AB-DTPA extraction $\left(1 \mathrm{M} \mathrm{NH}_{4} \mathrm{HCO}_{3}+0.005 \mathrm{M} \mathrm{DTPA}\right)$ as described by Naeem et al. [28]. Na, K, Mg, and Ca were analysed as described for soil in 2.2. Phosphorus (P) concentration was measured on a UV-visible spectrophotometer after developing yellow colour by vanadate-molybdate method [30].

\subsection{Pot Experiment}

The experiment was arranged in a completely randomized design (CRD) with two biochar levels ( \pm biochar: 0, $15 \mathrm{~g} / \mathrm{kg}$ soil) and two rice varieties (NERICA L19 and ROK3) in three replications. $5 \mathrm{~kg}$ air-dry soil was weighed and mixed with $75 \mathrm{~g}$ of rice straw biochar and placed into perforated black polythene bags of dimension $30 \mathrm{~cm}$ depth and $27.9 \mathrm{~cm}$ diameter. The soil was wetted and allowed to drain for 48 hours. Three (3) seeds were planted per polythene bag to a depth of $1.0 \mathrm{~cm}$ and a spacing of $2 \mathrm{~cm}$. Two weeks after planting, the seedlings were thinned to one stand by removing the less vigorous one. The experiment was conducted for eight weeks from the first week in May to the end of July. No fertilizer was applied. The soil was watered every three days until there was regular rainfall to provide sufficient moisture.

\subsection{Data Collection}

At eight weeks after planting, data was collected on plant height, tiller number, shoot and root biomass. Plant height was measured from the soil surface to the topmost leaf by placing a meter-rule vertically on the soil surface and a foot-rule horizontally at the height of the canopy and reading off from the meter rule. Tiller number was determined by counting the number of tillers for each plant stand. Data on biomass was collected by cutting the shoot from the soil surface and the roots were carefully removed by washing the soil from the roots with water. The fresh weights of shoot and root biomass were recorded and placed in an oven for drying at $75^{\circ} \mathrm{C}$.

\subsection{Data Analysis}

All data collected were subjected to statistical analysis: analysis of variance (ANOVA), mean comparison using GENSTAT Discovery Edition 3 software. Where significance of difference was found mean separation was done by the leas significant difference at $95 \%$ confidence interval. 


\section{Results}

\subsection{Properties of Rice Straw Biochar}

The properties of rice straw biochar are shown on Table 1. Biochar production using the top-lit-updraft pyrolysis stove was rapid and lasted for about 20 minutes. Biochar yield or recovery from the raw rice straw was on the average $29.7 \%$ with an ash content of $34.2 \%$. The derived rice straw biochar had low bulk density (0.75), high $\mathrm{pH}$ (9.3) and phosphorus (738 mg P/kg biochar). The cation exchange capacity (CEC $=44.2 \mathrm{cmol}+/ \mathrm{kg}$ biochar) was high and tice straw biochar was also rich in exchangeable cations especially $\mathrm{K}(39.7 \mathrm{cmol}+/ \mathrm{kg}$ biochar) as compared to $\mathrm{Mg}$ (5.8 cmol+/kg biochar) and $\mathrm{Ca}(12.6 \mathrm{cmol}+/ \mathrm{kg}$ biochar $)$.

\subsection{Effect of Rice Straw Biochar on Soil Properties}

As shown in Table 2, addition of rice biochar to soil (+biochar) improved soil physical and chemical properties as compared to the soil without biochar (control: -biochar). The biochar treated soil had higher available phosphorus (11.5 mg/kg soil), exchangeable cations ( $\mathrm{Na}, \mathrm{K}, \mathrm{Ca}$, and $\mathrm{Mg}-0.05,0.23,0.34$, and $0.31 \mathrm{cmol}+/ \mathrm{kg}$ soil respectively) and higher cation exchange capacity $(\mathrm{CEC}=10.2)$ than the control soil. This clearly indicated that rice straw biochar has the potential to improve soil physical and chemical properties.

\subsection{Effects of Rice Straw Biochar on the Growth of Two Rice Varieties}

The improvements of the soil physical and chemical properties due to application of rice straw biochar was reflected in the improved growth of rice varieties sown on the biochar treated soil. Plant height, tiller number and dry biomass weight of rice grown in soils amended with rice straw biochar were significantly higher than those of control soils.

\subsubsection{Effect on Plant Height}

Rice plants grown on soils treated with rice straw biochar were significantly $(\mathrm{p}<0.05)$ taller than those grown on soils without biochar treatment (Figure 1). For ROK3 rice variety, biochar application resulted in significantly taller plants $(56 \mathrm{~cm})$ than the control $(47.4 \mathrm{~cm})$. Similarly, rice plants of NERICA L19 variety grown on soils treated with biochar were significantly taller $(53.3 \mathrm{~cm})$ than those grown on the control soil $(43.4 \mathrm{~cm})$. The results showed the positive influence of rice straw biochar on plant height for both rice varieties. There was also a significant $(\mathrm{p}<0.05)$ difference in plant height between the two rice varieties (ROK3 and NERICA L19) with and without biochar application. There was no significant interaction between biochar treatment and rice variety for plant height. This implied that the influence of rice straw biochar on plant height was not dependent on variety.

\subsubsection{Effect on Tiller Number}

Application of rice straw to soil showed significant $(\mathrm{p}<0.05)$ difference in tiller numbers from the untreated soil

Table 1. Pyhsicochemical properties of rice straw biochar.

\begin{tabular}{|c|c|c|c|c|c|c|c|c|c|c|}
\hline \multirow{2}{*}{$\begin{array}{l}\text { Yield } \\
(\%)\end{array}$} & \multirow{2}{*}{$\mathrm{pH}$} & \multirow{2}{*}{$\begin{array}{l}\text { Ash } \\
(\%)\end{array}$} & \multirow{2}{*}{$\begin{array}{c}\text { Bulk } \\
\text { Density } \\
\left(\mathrm{g} / \mathrm{cm}^{3}\right)\end{array}$} & \multirow{2}{*}{$\begin{array}{c}\mathrm{C} \\
\text { (gC/kg } \\
\text { biochar) }\end{array}$} & \multirow{2}{*}{$\begin{array}{c}\mathrm{P} \\
\text { (mgP/kg } \\
\text { biochar) }\end{array}$} & \multirow{2}{*}{$\begin{array}{c}\text { CEC } \\
\text { (cmol+/kg } \\
\text { biochar) }\end{array}$} & \multicolumn{4}{|c|}{$\begin{array}{l}\text { Exchangeable Cations } \\
\text { (cmol+/kg biochar) }\end{array}$} \\
\hline & & & & & & & $\mathrm{Na}$ & $\mathrm{K}$ & $\mathrm{Mg}$ & $\mathrm{Ca}$ \\
\hline 29.7 & 9.3 & 34.2 & 0.75 & 455.8 & 738 & 44.2 & 7.6 & 39.7 & 5.8 & 12.6 \\
\hline
\end{tabular}

Table 2. Effects of rice straw biochar on the physicochemical properties of a fine sandy loam soil (Mokonde series).

\begin{tabular}{|c|c|c|c|c|c|c|c|c|}
\hline & \multirow{2}{*}{$\mathrm{pH}$} & \multirow{2}{*}{$\begin{array}{l}\text { Bulk Density } \\
\quad\left(\mathrm{g} / \mathrm{cm}^{3}\right)\end{array}$} & \multirow{2}{*}{$\begin{array}{c}\mathrm{P} \\
\text { (mg P/kg soil) }\end{array}$} & \multirow{2}{*}{$\begin{array}{c}\text { CEC } \\
\text { (cmol+/kg soil) }\end{array}$} & \multicolumn{4}{|c|}{ Exchangeable Cations (cmol+/kg soil) } \\
\hline & & & & & $\mathrm{Na}$ & $\mathrm{K}$ & Mg & $\mathrm{Ca}$ \\
\hline $\begin{array}{c}\text { Control } \\
\text { (-biochar) }\end{array}$ & 4.8 & 1.27 & 6.7 & 7.4 & 0.03 & 0.09 & 0.21 & 0.26 \\
\hline $\begin{array}{c}15 \text { g/kg soil } \\
\text { (+biochar) }\end{array}$ & 5.4 & 1.22 & 11.5 & 10.2 & 0.05 & 0.23 & 0.34 & 0.31 \\
\hline
\end{tabular}




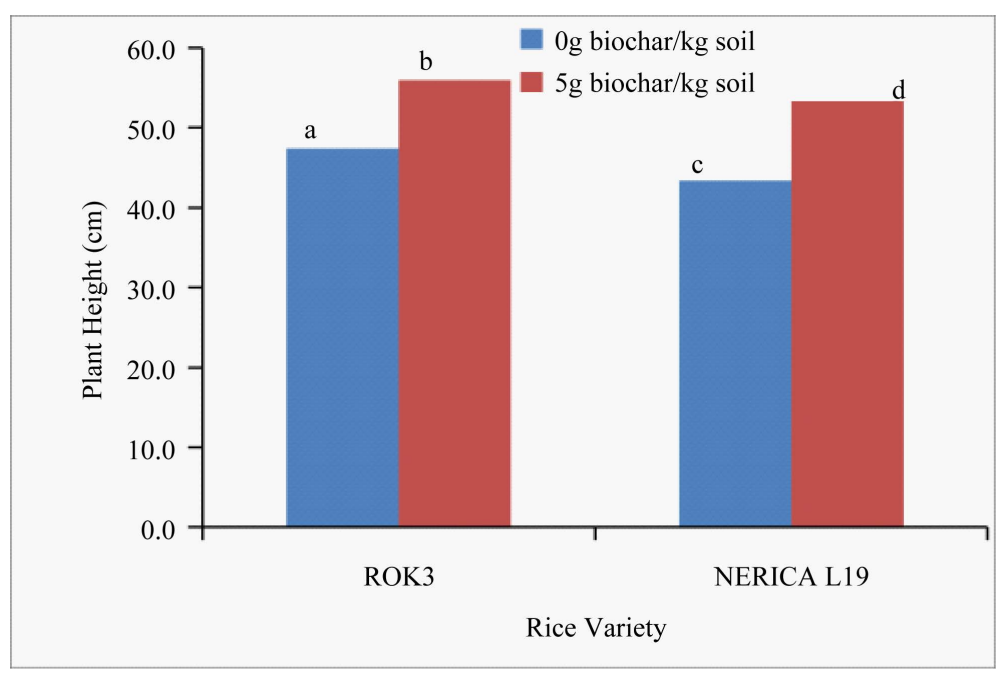

Figure 1. Effect of rice straw biochar on plant height of two rice varieties (ROK3 and NERICA L19) after eight weeks. Bars with same letters are not significantly differently from each other at $\mathrm{p}<0.05$. $\mathrm{LSD}_{0.5}=1.2$.

for both rice varieties (Figure 2). NERICA L19 grown on soil treated with rice straw biochar had significantly higher tiller numbers $(\mathrm{p}<0.05)$ than those grown on soil without biochar. Similarly, ROK3 rice variety showed a significant difference in tiller numbers between biochar treated and untreated soils. In the absence of biochar application, there was a significant difference $(\mathrm{p}<0.05)$ in tiller numbers between the two rice varieties. However, in the presence of biochar, the two rice varieties showed no significant difference in tiller numbers.

\subsubsection{Effect on Plant Biomass (Dry)}

The application of rice straw to soil showed remarkable difference in plant biomass (shoot and root) for both rice varieties (Figure 3(a) and Figure 3(b)). Shoot and root biomass of ROK3 varietytreated with biochar were significantly higher than those on soils without biochar treatment. Also, the shoot and root biomass weights of NERICA L19 variety on biochar treated soil were higher than those on untreated soil.

\section{Discussions}

In this study, conversion of rice straw biomass to biochar resulted in $29.7 \%$ recovery (Table 1 ). Although the temperature at which biochar was produced in this study was not measured, biochar recovery is generally affected by production temperature and residence time [31]. The derived rice straw biochar had high $\mathrm{pH}$ and good physicochemical properties (Table 1). Pyrolysis of raw biomass is known to produce biochar with high $\mathrm{pH}$, carbon, CEC, and cations [31]-[33]. Thus, rice straw biochar has the potential to be used as a fertilizer material. Consequently, application of biochar to soil increased $\mathrm{pH}$, reduced bulk density, increased cation exchange capacity and nutrient availability (Table 2). A lot of evidence exists in the literature indicating that biochar applications can improve soil properties [19] [34] [35]. [19] also showed that the application of biochar could increase soil organic carbon, soil pH, and CEC. The increase of CEC with the application of biochar has also been shown by [35]. In another study, [36] observed increase in $\mathrm{pH}$ in organic potting soil amended with biochar and [4] reported increased soil $\mathrm{pH}$ with application of rice straw biochar to soil.

The improvement in soil physicochemical properties due to biochar application was reflected in the growth and biomass production of the two rice varieties grown on soils treated with biochar as compared to the control without biochar. Plant height was increased relative to the control by $18.1 \%$ for ROK3 and $22.8 \%$ for NERICA L19 rice varieties.

The most remarkable differences were observed for tiller numbers (Figure 2) and biomass production (Figure 3). Application of biochar to soil has been shown to improve plant growth particularly on infertile soils [37]-[40]. The soil used in this study was acidic and generally low in fertility. Thus the application of rice straw biochar was found to improve soil fertility and hence plant growth. Biochar has been reported to enhance rice growth and yield in soils deficient in phosphorus [18]. On the contrary, [41] found no significant effect of 


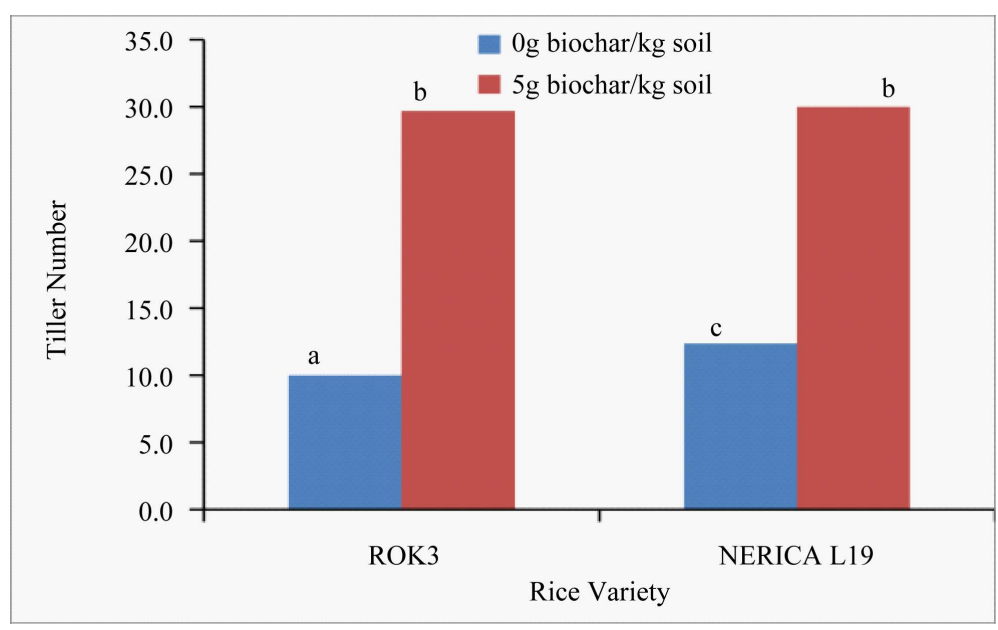

Figure 2. Effect of rice straw biochar on tiller number for two rice varieties (ROK3 and NERICA L19) after eight weeks. Bars with same letters are not significantlydifferently from each other at $\mathrm{p}<0.05 . \mathrm{LSD}_{0.5}=1.2$.

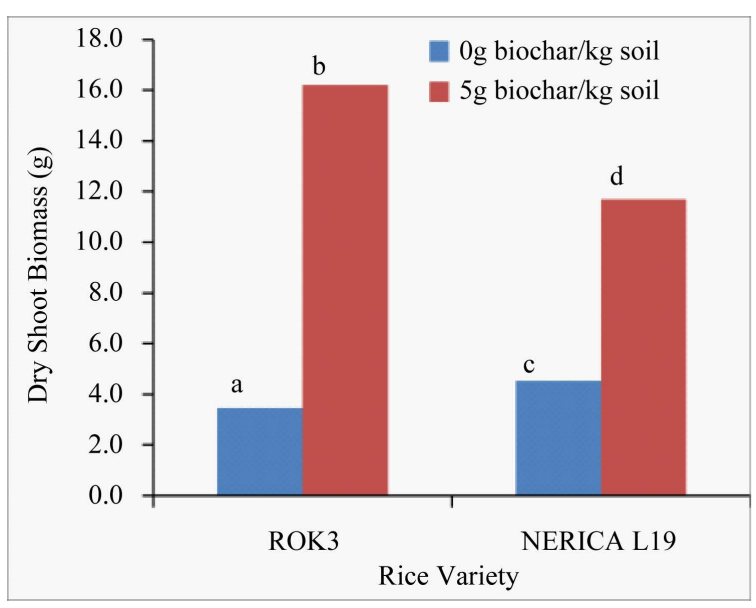

(a)

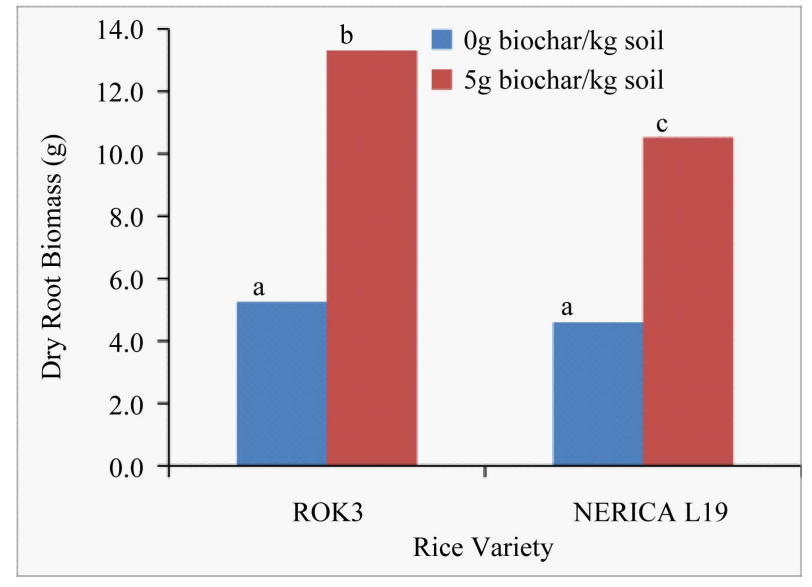

(b)

Figure 3. Effect of rice straw biochar on shoot (3a) and dry root (3b) biomass of two rice varieties (ROK3 and NERICA L19). after eight weeks. Means (bars) with same letters are not significantly differently from each other at $\mathrm{p}<0.05$. $\operatorname{LSD}_{0.5}=1.2$.

wheat-straw biochar amendment on rice growth in a relatively infertile soil. They attributed this to high phosphorus availability because they applied phosphorus in their experiment, thereby making it non-limiting. The soil used in this study was very low in phosphorus and therefore showed a significant response to the application of rice straw biochar which had a high content of phosphorus. On the whole, the observed increased in plant growth and biomass production could be attributed to the soil enhancing properties of rice straw biochar used in this study, particularly in the absence of fertilizer application. [42] reported increased plant height, root biomass and final biomass of lettuce and cabbage in soils receiving rice-husk biochar treatments. They observed that the greatest biomass increase was in soils without fertilizer application. Thus, as observed in this study, the application of biochar derived from rice-straw could be a valuable input in smallholder farms with limited financial resources for fertilizer purchase.

\section{Conclusion}

The results of this study showed that application of rice-straw biochar to soil can improve soil properties and rice growth. Specifically, application of rice-straw biochar at $15 \mathrm{~g} / \mathrm{kg}$ soil was found to significantly improve plant height, tiller numbers and biomass production relative to the control without biochar. The results indicated 
the importance of recycling rice straw through biochar production for improving soil fertility and crop growth in soils of low fertility, particularly in smallholder farming systems where access to inputs such as inorganic fertilizers is limited.

\section{Acknowledgements}

The authors would like to acknowledge the assistance of laboratory staff of the Njala University Quality Control Laboratory and the Njala Agricultural Research Centre Soil and Plant Analysis Laboratory.

\section{References}

[1] Tipayarom, D. and Oanh, N.T.K. (2007) Effects from Open Rice Straw Burning Emission on Air Quality in the Bangkok Metropolitan Region. ScienceAsia, 33, 339-345. http://dx.doi.org/10.2306/scienceasia1513-1874.2007.33.339

[2] Chen, K.S., Wang, H.K., Peng, Y.P., Wang, W.C., Chen, C.H. and Lai, C.H. (2008) Effects of Open Burning of Rice Straw on Concentrations of Atmospheric Polycyclic Aromatic Hydrocarbons in Central Taiwan. Journal of the Air \& Waste Management Association, 58, 1318-1327. http://dx.doi.org/10.3155/1047-3289.58.10.1318

[3] Lai, C.H., Chen, K.S. and Wang, H.K. (2009) Influence of Rice Straw Burning on the Levels of Polycyclic Aromatic Hydrocarbons in Agricultural County of Taiwan. Journal of Environmental Sciences, 21, 1200-1207. http://dx.doi.org/10.1016/S1001-0742(08)62404-3

[4] Kamara, A., Mansaray, M.M., Kamara, A. and Sawyerr, P.A. (2014) Effects of Biochar Derived from Maize Stover and Rice Straw on the Early Growth of their Seedlings. American Journal of Agriculture and Forestry, 2, 232-236. http://dx.doi.org/10.11648/j.ajaf.20140205.14

[5] Singh, B., Singh, B.P. and Cowie, A.L. (2010) Characterisation and Evaluation of Biochars for Their Application as a soil Amendment. Australian Journal of Soil Research, 48, 516-525. http://dx.doi.org/10.1071/SR10058

[6] Lehmann J., Rillig, M.C., Thies, J., Masiello, C.A., Hockaday, W.C. and Crowley, D. (2011) Biochar Effects on Soil Biota-A Review. Soil Biology and Biochemistry, 43, 1812-1836. http://dx.doi.org/10.1016/j.soilbio.2011.04.022

[7] Zimmerman, A.R. (2010) Abiotic and Microbial Oxidation of Laboratory-Produced Black Carbon (Biochar). Environmental Science \& Technology, 44, 1295-1301.

[8] Baldock, J.A. and Smernik, R.J. (2002) Chemical Composition and Bioavailability of Thermally Altered Pinus resinosa (Red Pine) Wood. Organic Geochemistry, 33, 1093-1109. http://dx.doi.org/10.1016/S0146-6380(02)00062-1

[9] Antal Jr., M.J. and Grønli, M. (2003) The Art, Science, and Technology of Charcoal Production. Industrial \& Engineering Chemistry Research, 42, 1619-1640. http://dx.doi.org/10.1021/ie0207919

[10] Amonette, J. and Joseph, S. (2009) Characteristics of Biochar: Micro Chemical Properties. In: Lehmann, J. and Joseph, S., Eds., Biochar for Environmental Management: Science and Technology, Earthscan, London, 33-52.

[11] Krull, E.S., Skjemstad, J.O., Graetz, D., Grice, K., Dunning, W., Cook, G. and Parr, J.F. (2003) 13C-Depleted Charcoal from C4 Grasses and the Role of Occluded Carbon in Phytoliths. Organic Geochemistry, 34, 1337-1352. http://dx.doi.org/10.1016/S0146-6380(03)00100-1

[12] Lehmann, J. (2007) A Handful of Carbon. Nature, 447, 143-144. http://dx.doi.org/10.1038/447143a

[13] Chan, K.Y., Van Zwieten, L., Meszaros, I., Downie, A. and Joseph, S. (2007) Agronomic Values of Green Waste Biochar as a Soil Amendment. Australian Journal of Soil Research, 45, 629-634. http://dx.doi.org/10.1071/SR07109

[14] Atkinson, C.J., Fitzgerald, J.D. and Hipps, N.A. (2010) Potential Mechanisms for Achieving Agricultural Benefits from Biochar Application to Temperate Soils: A Review. Plant and Soil, 337, 1-18. http://dx.doi.org/10.1007/s11104-010-0464-5

[15] Cornelissen, G., Martinsen, V., Shitumbanuma, V., Alling, V., Breedveld, G.D., Rutherford, D.W., Sparrevik, M., Hale, S.E., Obia, A. and Mulder, J. (2013) Biochar Effect on Maize Yield and Soil Characteristics in Five Conservation Farming Sites in Zambia. Agronomy, 3, 256-274. http://dx.doi.org/10.3390/agronomy3020256

[16] Liu, J., Schulz, H., Brandl, S., Miethke, H., Huwe, B. and Glaser, B. (2012) Short-Term Effect of Biochar and Compost on Soil Fertility and Water Status of a Dystric Cambisol in NE Germany under Field Conditions. Journal of Plant Nutrition and Soil Science, 175, 698-707. http://dx.doi.org/10.1002/jpln.201100172

[17] Schulz, H. and Glaser, B. (2012) Effects of Biochar Compared to Organic and Inorganic Fertilizers on Soil Quality and Plant Growth in a Greenhouse Experiment. Journal of Plant Nutrition and Soil Science, 175, 410-422. http://dx.doi.org/10.1002/jpln.201100143

[18] Asai, H., Samson, B.K., Stephan, H.M., Songyikhangsuthor, K., Homma, K., Kiyono, Y., Inoue, Y., Shiraiwa, T. and Horie, T. (2009) Biochar Amendment Techniques for Upland Rice Production in Northern Laos: 1. Soil Physical Properties, Leaf SPAD and Grain Yield. Field Crops Research, 111, 81-84. http://dx.doi.org/10.1016/j.fcr.2008.10.008 
[19] Shafie, S.T., Salleh, M.A., Hang, L.L., Rahman, M. and Ghani, W.A.W.A.K. (2012) Effect of Pyrolysis Temperature on the Biochar Nutrient and Water Retention Capacity. Journal of Purity, Utility Reaction and Environment, 1, 293307.

[20] Chan, K.Y., Van Zwieten, L., Meszaros, I., Downie, A. and Joseph, S. (2008) Using Poultry Litter Biochars as Soil Amendments. Australian Journal of Soil Research, 46, 437-444. http://dx.doi.org/10.1071/SR08036

[21] Joseph, S.D., Camps-Arbestain, M., Lin, Y., Munroe, P., Chia, C.H., Hook, J., Van Zwieten, L., Kimber, S., Cowie, A., Singh, B.P., Lehmann, J., Foidl, N., Smernik, R.J. and Amonette, J.E. (2010) An Investigation into the Reactions of Biochar in Soil. Australian Journal of Soil Research, 48, 501-515. http://dx.doi.org/10.1071/SR10009

[22] Novak, J.M., Busscher, W.J., Laird, D.L., Ahmedna, M., Watts, D.W. and Niandou, M.A.S. (2009) Impact of Biochar Amendment on Fertility of a Southeastern Coastal Plain Soil. Soil Science, 174, 105-112. http://dx.doi.org/10.1097/SS.0b013e3181981d9a

[23] Zimmerman, A.R., Gao, B. and Ahn, M.Y. (2011) Positive and Negative Carbon Mineralization Priming Effects among a Variety of Biochar-Amended Soils. Soil Biology \& Biochemistry, 43, 1169-1179. http://dx.doi.org/10.1016/j.soilbio.2011.02.005

[24] Van Vuure, W., Odell, R.T. and Sutton, P.M. (1972) Soil Survey of the Njala Area. Agronomy Department, Njala University College, Njala.

[25] Walkley, A. and Black, I.A. (1934) An Examination of Degtjareff Method for Determining Soil Organic Matter and a Proposed Modification of the Chromic Acid Titration Method. Soil Science, 37, 29-37. http://dx.doi.org/10.1097/00010694-193401000-00003

[26] Milford, M.H. (1997) Introduction to Soils and Soil Science Laboratory Exercises. Kendall/Hunt Publishing Company, Dubuque.

[27] Ahmedna, M., John, M.M., Clarke, S.J., Marshal, W.E. and Rao, R.M. (1997) Potential of Agricultural By-Products Based Activated Carbons for Use in Raw Sugar and Decolourization. Journal of the Science of Food and Agriculture, 75, 117-124. http://dx.doi.org/10.1002/(SICI)1097-0010(199709)75:1<117::AID-JSFA850>3.0.CO;2-M

[28] Naeem, M.A., Khalid, M., Arshad, M. and Ahmad, R. (2014) Yield and Nutrient Composition of Biochar Produced from Different Feedstocks at Varying Pyrolytic Temperatures. Pakistan Journal of Agricultural Sciences, 51, 75-82. http://www.pakjas.com.pk

[29] Gaskin, J.W., Steiner, C., Harris, K., Das, K.C. and Bibens, B. (2008) Effect of Low-Temperature Pyrolysis Conditions on Biochar for Agricultural Use. Transactions of the ASABE, 51, 2061-2069. http://dx.doi.org/10.13031/2013.25409

[30] Kuo, S. (1996) Phosphorus. In: Sparks, D.L., Ed., Methods of Soil Analysis: Chemical Methods. Part 3. Chemical Methods, SSSA Book Series, Madison, 869-919.

[31] Wu, W.X., Yang, M., Feng, Q.B., McGrouther, K., Wang, H.L., Lu, H.H. and Chen, Y.X. (2012) Chemical Characterization of Rice Straw-Derived Biochar for Soil Amendment. Biomass and Bioenergy, 47, 268-276. http://dx.doi.org/10.1016/j.biombioe.2012.09.034

[32] Masulili, A., Utomo, W.H. and Syechfani, M.S. (2010) Rice Husk Biochar for Rice Based Cropping System in Acid Soil 1. The Characteristics of Rice Husk Biochar and Its Influence on the Properties of Acid Sulfate Soils and Rice Growth in West Kalimantan, Indonesia. Journal of Agriculture Science, 3, 25-33.

[33] Milla, O.V., Rivera, E.B., Huang, W. J., Chien, C.C. and Wang, Y.M. (2013) Agronomic Properties and Characterization of Rice Husk and Wood Biochars and Their Effect on the Growth of Water Spinach in a Field Test. Journal of Soil Science and Plant Nutrition, 13, 251-266.

[34] Lehman, J., da Silva Jr., J.P., Steiner, C., Nehls, T., Zech, W. and Glaser, B. (2003) Nutrient Availability and Leaching in an Archaeological Anthrosol and a Ferralsol of the Central Amazon Basin: Fertilizer, Manure and Charcoal Amendments. Plant and Soil, 249, 343-357. http://dx.doi.org/10.1023/A:1022833116184

[35] Liang, B., Lehmann, J., Kinyangi, D., Grossman, J., O’Neill, B., Skjemstad, J.O., Thies, J., Luizao, F.J., Peterson, J. and Neves, E.G. (2006) Black Carbon Increases Cation Exchange Capacity in Soils. Soil Science Society of America Journal, 70, 1719-1730. http://dx.doi.org/10.2136/sssaj2005.0383

[36] Valerie, G., Dorais, M. and Menard, C. (2013) Organic Potted Plants Amended with Biochar: Its Effect on Growth and Pythium Colonization. Canadian Journal of Plant Science, 93, 1217-1227. http://dx.doi.org/10.4141/cjps2013-315

[37] Solaiman, Z.M., Murphy, D.V. and Abbott, L.K. (2012) Biochars Influence Seed Germination and Early Growth of Seedlings. Plant Soil, 353, 273-287. http://dx.doi.org/10.1007/s11104-011-1031-4

[38] Jones, D.L., Rousk. J., Edwards-Jones, G., DeLuca, T.H. and Murphy, D.V. (2012) Biochar-Mediated Changes in Soil Quality and Plant Growth in a Three Year Field Trial. Soil Biology \& Biochemistry, 45, 113-124. http://dx.doi.org/10.1016/j.soilbio.2011.10.012

[39] Major, J., Rondon, M., Molin, D., Riha, S.J. and Lehmann, J. (2010) Maize Yield and Nutrition during 4 Years of Biochar Application to a Colombian Savanna Oxisol. Plant Soil, 333, 117-128. 
http://dx.doi.org/10.1007/s11104-010-0327-0

[40] Lehmann, J. and Rondon, M. (2006) Bio-Char Soil Management on Highly Weathered Soils in the Humid Tropics. In: Uphoff, N., Ed., Biological Approaches to Sustainable Soil Systems, Taylor and Francis Group, Boca Raton, 517-530. http://dx.doi.org/10.1201/9781420017113.ch36

[41] Xie, Z., Xu, Y., Liu, G., Liu, Q., Zhu, J., Tu, C., Amonette, J.E., Cadisch, G., Yong, J.W.H. and Hu, S. (2013) Impact of Biochar Application on Nitrogen Nutrition of Rice, Greenhouse-Gas Emissions and Soil Organic Carbon Dynamics in Two Paddy Soils of China. Plant Soil, 370, 527-540. http://dx.doi.org/10.1007/s11104-013-1636-X

[42] Carter, S., Shackley, S., Sohi, S., Suy T.B. and Haefele, S. (2013) The Impact of Biochar Application on Soil Properties and Plant Growth of Pot Grown Lettuce (Lactuca sativa) and Cabbage (Brassica chinensis). Agronomy, 3, 404-418. http://dx.doi.org/10.3390/agronomy3020404 